\title{
How Motivation Works to Promote the Relationship Between Work Environment and Organizational Commitment to the Performance of Dharmasraya District Secretariat
}

\author{
Doli Putra Harahap ${ }^{1}$, Juli Ronaldi ${ }^{2}$, Darman $^{3}$, Yulina Eliza ${ }^{4}$ \\ Sekolah Tinggi Ilmu Ekonomi "KBP" Jl. Khatib Sulaiman No. 61 Padang \\ Correspondence email: yulinaeliza@akbpstie.ac.id
}

\begin{abstract}
The purpose of this study was to determine the effect of work environment on employee work motivation, determine the effect of organizational commitment on employee work motivation, know the effect of work environment on employee performance, find out the effect of organizational commitment on employee performance, find out the effect of work motivation on employee performance, know the role work motivation in mediating the relationship between work environment and employee performance and knowing the role of work motivation in mediating the relationship between organizational commitment and employee performance. The object of research is employees in the Regional Secretariat of Dharmasraya Regency with a population of 85 people. The sampling technique is done by non-probability sampling with saturation sampling technique where all members of the population are used so that the number of research samples is 85 people. The type of data used is primary data, the data collection method uses questionnaires with a Likert scale. Test the research instrument to test the validity and reliability. Data analysis techniques consist of test data description, assumption test, path analysis and hypothesis testing. The results of the study found that there was a positive and significant influence of the work environment on work motivation, there was a positive and significant effect on organizational commitment to work motivation, there was a positive and significant effect on the work environment on employee performance, there was a positive and significant effect on organizational commitment to employee performance, there was an influence positive and significant work motivation on employee performance, there is no role of work motivation in mediating the relationship between work environment and employee performance with the value of an indirect influence smaller than its direct influence, there is no role of work motivation in mediating the relationship between organizational commitment and employee performance with the value of the indirect effect is smaller than the direct effect. The results of the study suggest that to improve employee performance, it is expected that an increase in work motivation, a conducive work environment and an increase in organizational commitment.
\end{abstract}

Keywords: performance, work motivation, work environment and organizational commitment.

\section{Introduction}

The success of an organization in achieving its vision, mission, and purpose can not be separated from the implementation of the government's role or the organization itself. Various policies of the government in the administration of government at the level of government organizations both position and function of bureaucracy. The changes are, of course with the hope to meet the demands of the public interest and a strategy to face the challenges of globalization. According to Mangkunagara (2003), The performance is the result of the quality and quantity of work accomplished by an employee in performing their duties in accordance with the responsibilities given to him. Meanwhile, according toWinardi (2004) performance (performance) is the embodiment and the work or the work of someone. According to Rival (2005), The performance of the real behavior shown by everyone as the resulting performance by employees. Sopiah (2008)that the performance of individuals affected by the effort (effort), abilities (ability) and the environmental situation. A variety of things can affect the performance of which is owned by an employee, the physical working environment is one of them. Physical work environment is one of the closest thing to a person in the execution of his work. Physical working environment that is around employees need to be considered to bring good impact on the individual's performance. Comfort and security will be created for adequate physical working environment such as office layout that is comfortable, clean environment, good air exchange, color, lighting good lighting and so on.(Sedarmayanti, 2012).

Anoraga (2014)suggests factors that affect performance include the attractiveness of jobs, wages (incentive), willingness and labor protection, knowledge, environment and working conditions, career development expectations, involvement in the activities of the organization, attention and leadership boss. According to Bateman, Ferris and Strasser (1984) in(Timpe (2013)That the factors that affect performance include: ability, effort, task difficulty. However, a number of factors can affect the performance such as: the behavior, attitudes, actions of co-workers, subordinates or managers, resource constraints and economic circumstances.Daryanto (2010)suggests that the performance is affected by many factors including; prowess, skill, experience and ability of the individual.

Sekretariat Daerah Kabupaten Dharmasraya in carrying out their duties and functions are expected to carry out any activities in accordance with the vision, mission and strategy of the organization in achieving its objectives and 
Doli Putra Harahap et al, How Motivation Works to Promote the Relationship Between Work Environment and Organizational Commitment to the Performance of Dharmasraya District Secretariat

targets. This can only be achieved when the good performance of the apparatus. One measure of employee performance Sekretariat Daerah Kabupaten Dharmasraya is implementing programs that are planned each year. This can be served under the program as well as kegian and the achievement of each program.

Table 1

Achievement of Key Performance Sekretariat Daerah Kabupaten Dharmasraya Year 2017-2018

\begin{tabular}{|c|l|r|r|r|r|r|r|}
\hline \multirow{2}{*}{ No. } & \multirow{2}{*}{ Description } & \multicolumn{3}{|c|}{ 2017 } & \multicolumn{3}{|c|}{ 2018 } \\
\cline { 3 - 8 } & & amount & Realization & Performance (\%) & amount & \multicolumn{1}{c|}{ Realization } & Performance (\%) \\
\hline 1. & Indirect Expenditures & 6608667958 & 6561936201 & 99.29 & 6824450670 & 6122750812 & 89.72 \\
\hline 2. & Jump shopping & $31,101,575,141$ & $29,369,879,274$ & 94.43 & $39,107,269,810$ & $32,514,533,420$ & \\
\hline & amount & $37,710,243,099$ & $35,931,815,475$ & 95.28 & $45,931,720,480$ & $38,637,284,232$ & 83.14 \\
\hline
\end{tabular}

Source: Sekretariat Daerah Kabupaten Dharmasraya years 2017-2018

From Table 1 it can be concluded that the achievement of Key Performance Indicators Sekretariat Daerah Kabupaten Dharmasrayayears 2017 to 2018 was still below the target set. Achievement of the main indicators in 2018 was $84.12 \%$ down $11.17 \%$ compared to the achievement in 2017 is $95.28 \%$. This indicates that the performance of the Staff Sekretariat Daerah Kabupaten Dharmasraya still low. Many factors affect the performance of the Staff Sekretariat Daerah Kabupaten Dharmasraya. From initial observations by the author predicted factor affecting the performance of employees is the physical environment, organizational commitment and work motivation. According toNitisemito (2003) work environment is everything that is around employees and can affect in carrying out the tasks entrusted to him for example with the air conditioner (AC), adequate lighting and so on.

Table 2

Employee Attendance Data Sekretariat Daerah Kabupaten Dharmasraya January s / d December 2018

\begin{tabular}{|c|c|c|c|c|c|c|}
\hline \multirow{2}{*}{ Month } & \multicolumn{2}{|c|}{ Total Employees (\%) } & \multicolumn{2}{|c|}{ Attendance (\%) } & \multicolumn{2}{|c|}{ Absenteeism (\%) } \\
\hline & Person & $\%$ & Person & $\%$ & Person & $\%$ \\
\hline January & 85 & 100 & 72 & $85 \%$ & 13 & $15 \%$ \\
\hline February & 85 & 100 & 74 & $87 \%$ & 11 & $13 \%$ \\
\hline March & 85 & 100 & 73 & $86 \%$ & 12 & $14 \%$ \\
\hline April & 85 & 100 & 71 & $84 \%$ & 14 & $16 \%$ \\
\hline May & 85 & 100 & 68 & $80 \%$ & 17 & $20 \%$ \\
\hline June & 85 & 100 & 66 & $78 \%$ & 19 & $22 \%$ \\
\hline July & 85 & 100 & 68 & $80 \%$ & 17 & $20 \%$ \\
\hline August & 85 & 100 & 72 & $85 \%$ & 13 & $15 \%$ \\
\hline September & 85 & 100 & 75 & $88 \%$ & 10 & $12 \%$ \\
\hline October & 85 & 100 & 71 & $84 \%$ & 14 & $16 \%$ \\
\hline November & 85 & 100 & 73 & $86 \%$ & 12 & $14 \%$ \\
\hline December & 85 & 100 & 72 & $85 \%$ & 13 & $15 \%$ \\
\hline
\end{tabular}

Source: Sekretariat Daerah Kabupaten Dharmasraya, 2018

On the other hand success is inseparable from the employee-owned employee commitment in carrying out their duties, employees with high commitment can be expected to show optimum performance. Someone who joined the organization in a company is required their commitment in itself.Davis, Keith (2001)define organizational commitment as a gesture that showed "loyalty" of employees and a continuous process of how an organization's members expressed their concern to the organization's success and goodness. The commitment includes involvement also work. This is because between job involvement and organizational commitment are very closely related. Work engagement as the degree of willingness to integrate itself with the work, invest your time, talents and energy to work, and considers his work as a major part of his life. The stronger the commitment, the stronger the tendency of a person to be directed at the action in accordance with the standards (in Syafrida, 2013). From Table 2 it can be seen that the presence of an employee at the Sekretariat Daerah Kabupaten Dharmasraya not maximized it will affect the performance of the resulting employee Sekretariat Daerah Kabupaten Dharmasraya. Another factor affecting employee performance Sekretariat Daerah Kabupaten Dharmasraya is working motivation. Motivation is the drive, effort and desire that is in man which activate, energize and redirect the behavior to perform the tasks well within the scope of his job(Sedarmayanti, 2011), NextRobbins (2001)defines motivation as a process that will determine the intensity, direction, and persistence of individuals in order to achieve the target. Motivation as a process that stems from the strength in terms of physiological and psychological or behavioral needs that result or encouragement aimed at a goal or incentive (Moekijat, 2011).

Of the above phenomena, it can be prepared a number of formulation of the problem as follows:

1. How will the work environment on employee motivation Sekretariat Daerah Kabupaten Dharmasraya?

2. How will the organization's commitment to employee motivation Sekretariat Daerah Kabupaten Dharmasraya? 
3. How will the work environment on employee performance Sekretariat Daerah Kabupaten Dharmasraya?

4. How will the organization's commitment to employee performance Sekretariat Daerah Kabupaten Dharmasraya?

5. How does the work motivation on employee performance Sekretariat Daerah Kabupaten Dharmasraya?

6. How does the role of motivation to work in mediating the relationship between the work environment and employee performance Sekretariat Daerah Kabupaten Dharmasraya?

7. How does the role of motivation to work in mediating the relationship between organizational commitment and performance of employees of the Sekretariat Daerah Kabupaten Dharmasraya?

\section{Performance (Performance)}

Mangkunagara (2016)defining performance (performance) as follows: performance is the result of the quality and quantity of work achieved an employee in performing their duties in accordance with the responsibilities given to him. WhileBernardin \& Russell (1993) in Handoko (2010), Saying that the employee's performance depends on the ability, work effort and employment can be judged from the out put. Timpe (2013), suggests that the performance (performance) is: The performance level of the individual, the desired result of individual behavior. Hasibuan (2018) said there are several factors that affect a person's performance, namely: commitment, motivation, ability, discipline, responsibility, and working conditions of the same. Thus we can conclude the factors that may affect the performance of an employee is compensated, into the climate, motivation, supervision, leadership, boss, salary (compensation). Given the importance of performance, then in his duties are required to have the ability and the various skills so that they can perform their jobs well.Nitisemito (2003) stated that performance measurement can be seen from a fundamental behavioral assessment, namely: a) the quality of work, b) the quantity of labor, and c) the employment relationship.

\section{Work environment}

Every organization, in general, both large, medium and small, all of them will interact with the environment in which an organization or company is located. The environment itself changes-parubahan so, organizations or companies can survive is an organization that can adapt to environmental changes. Instead, the organization will experience a period of destruction if the organization does not pay attention to developments and changes in the surrounding environment. According to Terry (2003), the work environment can be defined as the forces that affect, either directly or indirectly to the performance of the organization or company.According to Sedarmayanti (2009)declare that in outline, the type of work environment is divided into 2 physical work environment and non-physical work environment.

\section{Organizational commitment}

According Mowday (2005) in Syafrida (2013) organizational commitment is the relative strength of individual identifying her involvement in the organization. It is characterized by three things: (1) the hiring of the values and goals of the organization, (2) the readiness and willingness of employees to strive earnestly on behalf of the organization, and (3) the desire of employees to maintain their membership in the organization ( be part of the organization). Organizational commitment expressed by Robbin (2011) with three components of the organization are: affective commitment (affective commitment), commitment kontinuans (continuance commitment), and normative commitment (normative commitment). It is common of the three components of this commitment is the commitment seen as a psychological condition which describes the relationship of the individual with the organization and has implications in the decision to continue or not membership in the organization.

\section{Work motivation}

Flippo (2009)motivation to work as a skill in combining the interests of employees and the interests of the organization so desires satisfied employees in conjunction with the achievement of organizational goals. These wishes to provide a series of tools that work motivation can be used by managers to motivate behavior in the desired objectives improve employee performance. Motivation byMathis \& Jackson (2001)a desire within oneself that cause people to take action. Motivation as a driver that leads to the goal, to understand what motivates employees, will greatly assist in improving employee satisfaction. While Gibson, Ivancevich (2010)express understanding of motivation to work as a concept that describes the forces that exist within the employees who initiate and direct behavior. Gibson (2010) to find out what people want from their jobs.

Based on theoretical basis, review the results of previous studies, it can be described the relationship between the three variables, namely free work environment, work motivation and organizational commitment organizational commitment with the dependent variable is the performance of employees who can be seen in the framework as follows: 
Doli Putra Harahap et al, How Motivation Works to Promote the Relationship Between Work Environment and Organizational

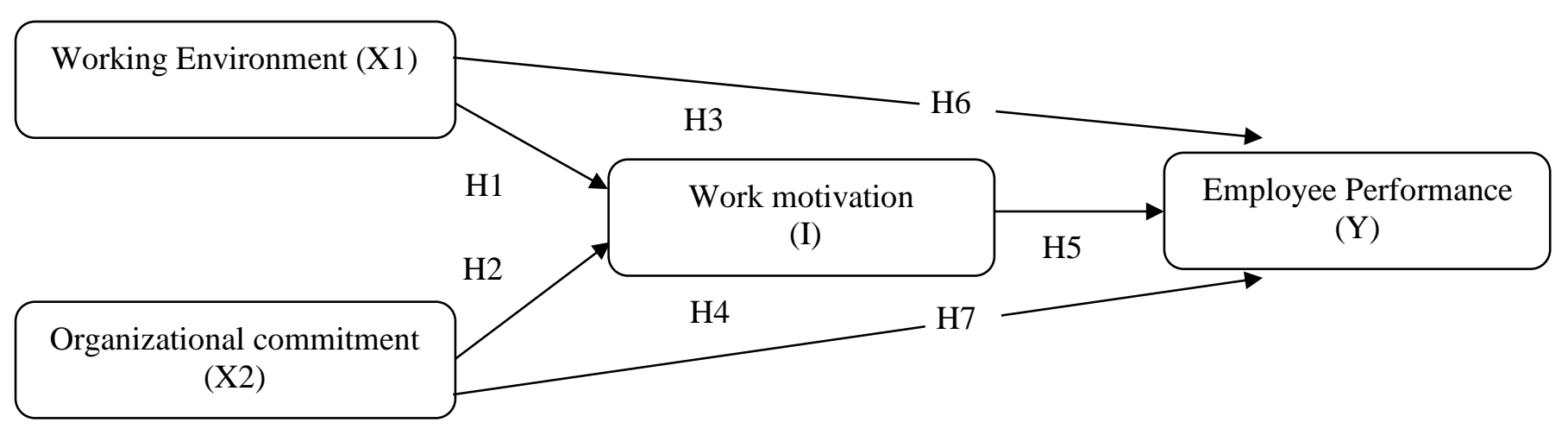

Figure 1

Framework

Based on the foundation of terori framework described above, it can dikemukan hypothesis is as follows:

1. Work environment positive effect on employee motivation Sekretariat Daerah Kabupaten Dharmasraya.

2. Organizational commitment positively affects employee motivation Sekretariat Daerah Kabupaten Dharmasraya.

3. The working environment has a positive effect on employee performance Sekretariat Daerah Kabupaten Dharmasraya.

4. Organizational commitment positively affects employee performance Sekretariat Daerah Kabupaten Dharmasraya.

5. Work motivation has a positive effect on employee performance Sekretariat Daerah Kabupaten Dharmasraya.

6. Work motivation plays a role in mediating the relationship between the work environment and employee performance Sekretariat Daerah Kabupaten Dharmasraya.

7. Work motivation plays a role in mediating the relationship between organizational commitment and performance of employees of the Sekretariat Daerah Kabupaten Dharmasraya.

\section{Methods}

Sugiyono (2010) argues that the population is generalization region consisting of the object or subject in the quantity and specific characteristics defined by the researchers to learn and then be deduced. The study population was all employees Sekretariat Daerah Kabupaten Dharmasrayawhich amounts to 85 people. Due to the number of population is still considered to be relatively small at around below 100 then the approach used for sampling in this study were calculated using the Census. the method of sampling to determine the number of samples is equal to the population (number equal to the sample population). This is in accordance with the opinion Arikunto (2002), that the sample is a portion of the population that respondents to the study, the large sample size depends on a lot of the study population, where the population is relatively small or equal to 100, then all of them can be used as a sample, the sample is taken of the total population that is that as many as 85 people.

In this study, the type of data used is primary data and secondary data. Primary data is data collected directly by the researcher of the field that is the data taken from the respondents, this data is the answer to a questionnaire distributed to respondents. Secondary data is data that diproleh of the object of research and has been documented. This data can be diproleh through books and other reports. Source of data derived from the Sekretariat Daerah Kabupaten Dharmasrayaform of data on the number and characteristics of employees, employee attendance and so on. Besides, the source of the data obtained directly from the Staff Sekretariat Daerah Kabupaten Dharmasraya about their perceptions of the variable performance of employees, work environment, work motivation and organizational commitment.

\section{Path analysis}

Path analysis (path analysis) is the test used to analyze the pattern of relationships among variables. Path analysis is the use of regression analysis to estimate hubungankasualitas between variables (causal models) are predetermined based on the theory. According to Imam Ghozali, (2016). Analysis track aims to explain the direct and indirect result of a set of variables, as variables cause, against a set of other variables is a variable effect. Path analysis is an extension of regression analysis. In regression analysis the effort to learn the relationship between variables is never questioned why the relationship exists or not.

\section{Hypothesis testing \\ Substructure Hypothesis Testing 1}

To analyze the effect of the work environment variables $\left(\mathrm{X}_{1}\right)$ and organizational commitment $(\mathrm{X} 2)$ on work motivation (I) are presented in Table 3 below: 
Doli Putra Harahap et al, How Motivation Works to Promote the Relationship Between Work Environment and Organizational Commitment to the Performance of Dharmasraya District Secretariat

Table 3

Work Environment Influence And Organizational Commitment To Work Motivation

\begin{tabular}{lrrr}
\hline \multicolumn{1}{c}{ Variables that influence } & standardized coefficients & Sig & 0,531 \\
\hline Work environment $\left(\mathrm{X}_{1}\right)$ & .200 & 0,001 \\
Organizational commitment $\left(\mathrm{X}_{2}\right)$ & 0,039 \\
\hline
\end{tabular}

Source: results of primary data processing, 2019

Based on the above it can be seen Table 3 substructure equation 1 is:

$\mathrm{I}=0,531 \mathrm{X}_{1}+0,2 \mathrm{X}_{2} \quad$ Description substructure equation 1 :

$\mathrm{b} 1=0,53$; it means that there is a positive influence between work environment variables $\left(\mathrm{X}_{1}\right)$ on work motivation $(\mathrm{I})$. Hal suggests that a more conducive work environment, it will increase work motivation employees.

$\mathrm{b} 2=0.2$; it means that there is a positive influence between the variables of organizational commitment $\left(\mathrm{X}_{2}\right)$ on work motivation (I). Hal showed that the higher the commitment of the organization, it will increase work motivation employees.

From Table 3 can do partial test each variable to variable causes the following consequences:

1. Influence at Work $\left(\mathrm{X}_{1}\right)$ Work Motivation (I)

The analysis results work environment variables $\left(X_{1}\right)$ to work motivation variable $(I)$ obtained Pix 1 value $=0,531$ with significant levels 0,000 levels $<0.05$. The analysis showed that a significant difference between the work environment to employee motivation Sekretariat Daerah Kabupaten Dharmasraya. This may imply that the work environment positive and significant effect on work motivation. Thus, the first hypothesis $\left(\mathrm{H}_{1}\right)$ in this study that states that the working environment positive and significant effect on work motivation Sekretariat Daerah Kabupaten Dharmasraya staff, declared unacceptable. This means that the better the work environment perceived by the employees of the Sekretariat Daerah Kabupaten Dharmasrayathen the condition can affect positively and significantly related to employee motivation in working at the Sekretariat Daerah Kabupaten Dharmasraya. Conversely, if more is not better working environment adopted by the Staff Sekretariat Daerah Kabupaten Dharmasraya then the condition can lead to increasingly poor motivation of employees working with the assumption that other variables held constant in addition to the work environment. The working environment has a relationship with work motivation. Physical work environment and non-physical is something that exists around the workers who can influence in running the tasks given. Employee motivation is internal factors which are owned by employees, where employee motivation is the driving force that creates the administration excitement somebody working for them to cooperate, to work effectively and integrated with all of its efforts to achieve satisfaction (Ferry et al., 2017).

2. Influence of Organizational Commitment $\left(\mathrm{X}_{2}\right)$ Work Motivation (I)

Results of analysis variables influence organizational commitment $\left(\mathrm{X}_{2}\right)$ on work motivation (I) values obtained with the level $\mathrm{PiX}_{2}=0.2$ significant level of $0.039<0.05$. The analysis showed that there is significant influence between the variables of organizational commitment to employee motivation variable Sekretariat Daerah Kabupaten Dharmasraya. This may imply that the variable organizational commitment and significant positive effect on employee motivation. Thus, the second hypothesis $\left(\mathrm{H}_{2}\right)$ in this study that states that organizational commitment and significant positive effect on work motivation Sekretariat Daerah Kabupaten Dharmasraya staff, declared unacceptable. This means that if the higher organizational commitment Sekretariat Daerah Kabupaten Dharmasraya staff, it will be better the Regional Secretariat of employee motivation Dharmasraya. Conversely, if the lower the organizational commitmentemployees work at the Sekretariat Daerah Kabupaten Dharmasraya, it will lower the motivation of employees working at the Sekretariat Daerah Kabupaten Dharmasraya assuming other variables held constant besides organizational commitment.

According to Mathis and Jackson (2011) regarding the organizational commitment is the extent to which employees believe and accept the organization's goals and have a desire to remain with the organization. Employees who have a strong desire to achieve corporate goals and want to remain in the organization then he will have a high motivation to work so that his desire is achieved because the motivation is something that started the movement, something started to act a certain way.

Results substructure 1 is shown in Figure 2 below: 
Doli Putra Harahap et al, How Motivation Works to Promote the Relationship Between Work Environment and Organizational

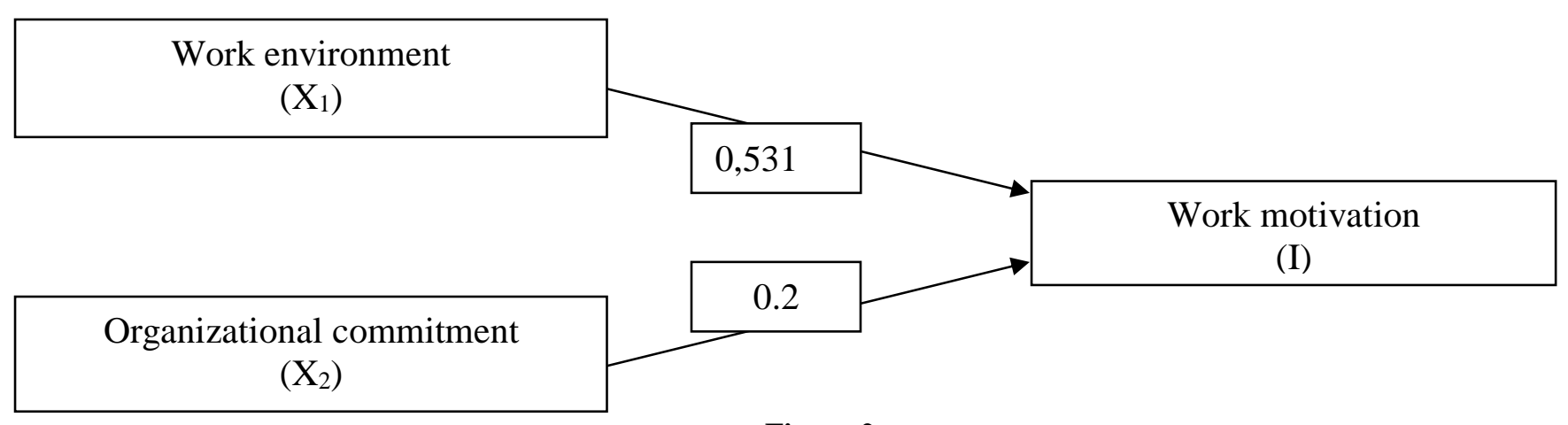

Figure 2

Substructure 1. Results of the Work Environment Influence and Organizational Commitment Motivation to Work

\section{Hypothesis Testing Substructure 2}

To analyze the effect of the work environment variables $\left(\mathrm{X}_{1}\right)$ and organizational commitment $\left(\mathrm{X}_{2}\right)$ and motivation (I) to employee performance (Y) are presented in Table 4 below:

Table 4

Influence of Working Environment, Organizational Commitment, Work Motivation on Employee Performance

\begin{tabular}{lrr}
\hline \multicolumn{1}{c}{ Variables that influence } & standardized coefficients & Sig \\
\hline Work environment (X1) & 0,794 & 0,000 \\
Organizational commitment (X2) & 0,125 & 0,025 \\
Work motivation (I) & 0.135 & 0,040 \\
\hline
\end{tabular}

Source: results of primary data processing, 2019

Based on table 4 then the equation structure 2 in the form: $\mathrm{Y}=0,794 \mathrm{X}_{1} 0,125 \mathrm{X}_{2}+0.135+\mathrm{I}$

Description substructure equation 2:

$\mathrm{b} 1=0,794$, it means that there is a positive influence between work environment $\left(\mathrm{X}_{1}\right)$ on the performance $(\mathrm{Y})$. This suggests that a more conducive work environment, it will be able to increaseperformance,

$\mathrm{b} 1=0.125$, meaning that there is a positive influence between organizational commitment $\left(\mathrm{X}_{2}\right)$ on the performance (Y).This suggests that the higher organizational commitment, it will be able to increaseperformance,

$\mathrm{b} 1=0.135$, meaning that there is a positive influence between work motivation (I) on the performance (Y). This shows that the enhanced motivation to work, then it will be able to increaseperformance.

From Table 4 can do partial test each variable to variable causes the following consequences:

1. Influence at Work $\left(\mathrm{X}_{1}\right)$ Against Employee performance (Y)

Based on the results of the third hypothesis testing, it was found that the work environment positive and significant effect on the performance of the Staff Sekretariat Daerah Kabupaten Dharmasraya path coefficient value of the work environment variable is 0,794 and 0,000 significant value smaller than $\alpha=0.05$. This may imply that the work environment positive and significant effect on employee performance. Thus, the third hypothesis $\left(\mathrm{H}_{3}\right)$ in this study that states that the working environment positive and significant effect on employee performance Sekretariat Daerah Kabupaten Dharmasraya, declared unacceptable. This means that the better the work environment perceived by the employees of the Sekretariat Daerah Kabupaten Dharmasraya then the situation would be a positive and significant influence on the performance of employees in work at the Sekretariat Daerah Kabupaten Dharmasraya. Conversely, if more is not better working environment adopted by the Staff Sekretariat Daerah Kabupaten Dharmasraya then the condition can lead to increasingly poor performance of employees assuming other variables held constant in addition to the work environment. Nitisemito (2011) states the working environment is everything that is around the workers who can influence him in performing the tasks carried. Moekijat (2002) physical work environment is something that is about the workers that include lighting, color, air and sound. Furniture, fixtures, office machines used and the layout affects the physical work environment office in general, conditions of work should be fun, easy and resulting habits of a good job, good condition causing performance of a company's employees will be increased so the company's objectives will be achieved.

2. Influence of Organizational Commitment $\left(\mathrm{X}_{1}\right)$ Against performance of employees (Y)

Based on the results of the fourth hypothesis testing, it was found that organizational commitment variable positive and significant impact on the performance of employees of the Sekretariat Daerah Kabupaten Dharmasraya with organizational commitment variable path coefficient is 0.125 and 0.025 significant. The significant value is smaller than $\alpha=0.05$. This may imply that the variable organizational commitment and significant positive effect on 
employee performance. Thus, the fourth hypothesis (H4) in this study that states that organizational commitment and significant positive effect on employee performance Sekretariat Daerah Kabupaten Dharmasraya, declared unacceptable. This means that if the higher organizational commitment Sekretariat Daerah Kabupaten Dharmasraya staff, the higher the performance of the Staff Sekretariat Daerah Kabupaten Dharmasraya. Conversely, if increasingly lower employee organizational commitment Sekretariat Daerah Kabupaten Dharmasraya, it will lower the performance of employees at the Sekretariat Daerah Kabupaten Dharmasraya assuming other variables held constant besides organizational commitment. Organizational commitment is something that shows responsibility and concern for someone to tasks in the office. Where an employee has a responsibility towards his job, increased interest in his work, and job loyalty discount to the job. Employees who have a high organizational commitment will yield high performance for organisasinyan. Then their positive influence between organizational commitment to employee performance is quite reasonable.

3. Influence of Work Motivation (I) Against Employee performance (Y)

Based on the results of the fifth hypothesis testing, it was found that work motivation positive and significant effect on the performance of employees of the Sekretariat Daerah Kabupaten Dharmasraya with the value of work motivation path coefficient is 0.135 and significant at 0,040 . The significant value is smaller than $\alpha=0.05$. This may imply that work motivation variable positive and significant impact on employee performance. Thus, the fifth hypothesis (H5) in this study that states that motivation positive and significant effect on employee performance Sekretariat Daerah Kabupaten Dharmasraya, declared unacceptable.

This means that if the higher employee motivation Sekretariat Daerah Kabupaten Dharmasraya, the higher the performance of the Staff Sekretariat Daerah Kabupaten Dharmasraya. Conversely, if diminishing employee motivation in working at the Sekretariat Daerah Kabupaten Dharmasraya, it will lower the performance of the Staff Sekretariat Daerah Kabupaten Dharmasraya assuming other variables held constant besides work motivation. Theoretically the above statement in accordance raised by Ernest J. Mc Cormick (Mangkunagara 2011) that work motivation is defined as conditions that affect evoke, directing and maintaining behavior associated with the work environment. From these definitions, basically stated that motivation is closely related to the effort (effort) someone at work. This opinion is supported by the statement in Mangkunagara Kinlaw (2011), that an employee who has a high work motivation is someone who is constantly trying to do the best and be willing to take the time and extra effort to do its job. Employees who have low motivation is a person who often do not want to try to do the best, and rarely take the time and extra effort to do its job. Employee be motivated when he perceives his work dealing with something that is important to him.

The results of the substructure 2 can be shown in Figure 3 below:

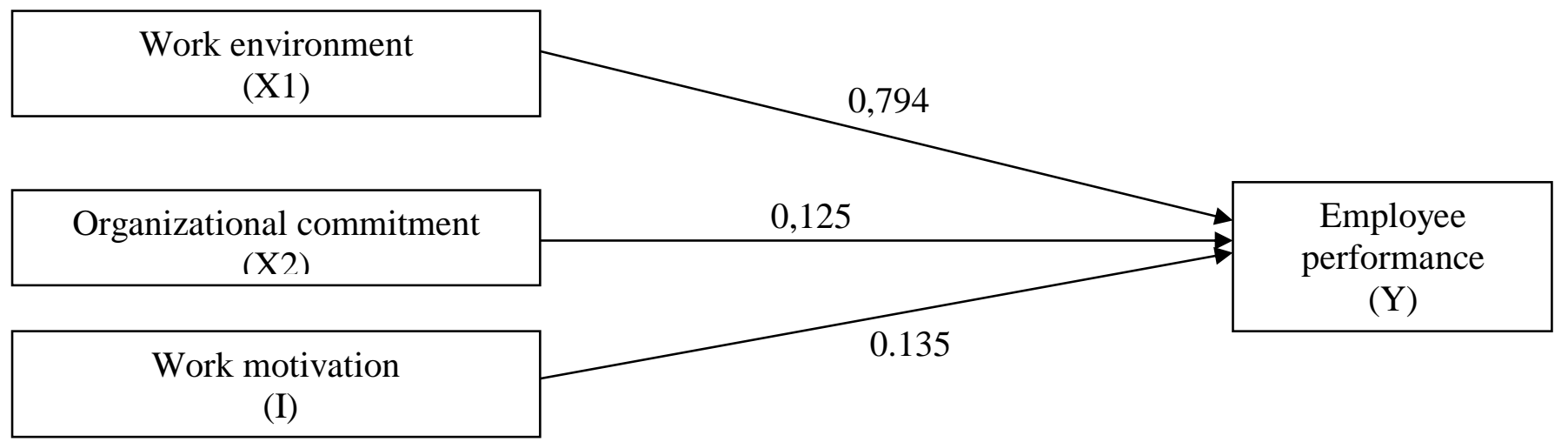

Figure 3

Substructure 2. Results Effect of Work Environment, and Organizational Commitment Work Motivation on Employee Performance

\section{Coefficient of Determination}

The result of the calculation of the coefficient of determination for substrukur equations 1 and 2 can be shown in Table 5 below:

Table 5

Calculation Results Coefficient of Determination

\begin{tabular}{rlr}
\hline Equation & \multicolumn{1}{c}{ Variable Relations } & R Square \\
\hline substructure 1 & Commitment work environment and work organization Motivation & 0.33 \\
substructure 2 & $\begin{array}{l}\text { Work environment and organizational commitment and work motivation on employee } \\
\text { performance }\end{array}$ & 0,795 \\
\hline
\end{tabular}

Source: results of primary data processing, 2019 
Table 5 can be calculated based on the value of $\mathrm{R}^{2}$ total as follows:

1. For substructures equation 1 :

$$
\begin{aligned}
& \mathrm{P}_{\varepsilon 1}=\sqrt{1-\mathrm{R}^{2}} \\
& \mathrm{P}_{\varepsilon 1}=\sqrt{1-0,33} \\
& \mathrm{P}_{\varepsilon 1}=\sqrt{0,67} \\
& \mathrm{P}_{\varepsilon 1}=0,819
\end{aligned}
$$

2. For substructures equation 2:

$$
\begin{aligned}
& \mathrm{P}_{\varepsilon 2}=\sqrt{1-\mathrm{R}^{2}} \\
& \mathrm{P}_{\varepsilon 2}=\sqrt{1-0,795} \\
& \mathrm{P}_{\varepsilon 2}=\sqrt{0,205} \\
& \mathrm{P}_{\varepsilon 2}=0,453
\end{aligned}
$$

3. Total $\mathrm{R}^{2}=1-(0.819 \times 0.453)=1$ to $0.3706=0.6294$

From the above results obtained by the coefficient of determination total of 0.6294 . This means that $62.94 \%$ of employee performance can be explained by the work environment, organizational commitment and work motivation. While the remaining $37.06 \%$ is explained by other variables not examined in this study.

Path Analysis (Path Analysis)

Path analysis (path analysis) is the test used to analyze the pattern of relationships among variables. Path analysis is the use of regression analysis to assess the causality relationship between variables (causal models) are predetermined based on the theory. Intervening are variables that mediate the relationship between endogenous variables to exogenous variables. Model studies give their indirect effect on the work environment and organizational commitment to employee performance through motivation to work. Test intervening done using path analysis or path analysis as follows:

1. Employee motivation role in mediating the relationship between the work environment and employee performance Sekretariat Daerah Kabupaten Dharmasraya.

To determine the effect of an exogenous variable to the endogenous variables either directly or indirectly, can be seen as follows: The direct effect of the variable $\mathrm{X} 1$ to $\mathrm{Y}$

$\mathrm{Y} \leftarrow \mathrm{X}_{1} \rightarrow \mathrm{Y}(\rho \mathrm{yx} 1)(\rho \mathrm{yx} 1)=(0.794) \mathrm{x}(0,794)=0.63=63 \%$

The indirect effect of $\mathrm{X} 1$ to $\mathrm{Y}$ through the I

$\mathrm{Y} \leftarrow \mathrm{X}_{1} \Omega \mathrm{I} \rightarrow \mathrm{Y}(\rho \mathrm{yx} 1)(\mathrm{Ix} 1 \rho)(\rho \mathrm{yi})=(0.794) \mathrm{x}(0.531) \mathrm{x}(0.135)=0.057=5.7 \%$

Based on the above calculation shows that the direct effect of the work environment on employee performance is of $0.63(63 \%)$, while the indirect effect of the work environment variables on the performance of employees through work motivation of $0.057(5.7 \%)$. From these results it can be concluded that work motivation can not play a role in mediating the relationship between the work environment and employee performance because the value of the coefficient is smaller than the direct effect $(0.057<0.63)$. This means that with the role of motivation to work then do not improve the work environment influence on employee performance Sekretariat Daerah Kabupaten Dharmasraya.

2. Employee motivation role in mediating the relationship between organizational commitment and performance of employees of the Sekretariat Daerah Kabupaten Dharmasraya.

To determine the effect of an exogenous variable to the endogenous variables either directly or indirectly, can be seen as follows: The direct effect of the variable $\mathrm{X} 1$ to $\mathrm{Y}$

$\mathrm{Y} \leftarrow \mathrm{X}_{1} \rightarrow \mathrm{Y}(\rho \mathrm{yx} 1)(\rho \mathrm{yx} 1)=(0.125) \times(0.125)=0.016=1.6 \%$

The indirect effect of $\mathrm{X}_{1}$ to $\mathrm{Y}$ via $\mathrm{X}_{3} \mathrm{Y} \leftarrow \mathrm{X}_{1} \Omega \mathrm{I} \rightarrow \mathrm{Y}(\rho \mathrm{yx} 1)(\mathrm{Ix} 2 \rho)(\rho \mathrm{yi})=(0.125) \times(0.2) \times(0.135)=0.003=$ $0.3 \%$

Based on the above calculation shows that the direct effect of organizational commitment to employee performance amounted to $0,016(1.6 \%)$, while the indirect influence variable organizational commitment to employee performance through work motivation of $0,003(0.3 \%)$. From these results it can be concluded that work motivation can not play a role in mediating the relationship between organizational commitment and performance of employees because the value of the coefficient is smaller than the direct effect $(0.003<0.016)$. This means that with the role of motivation to work then do not increase the effect of organizational commitment to employee performance Sekretariat Daerah Kabupaten Dharmasraya. 
1. There is a positive and significant impact on work motivation work environment with significant values $<0.05$. The better the work environment also increase the motivation of the employee Sekretariat Daerah Kabupaten Dharmasraya..

2. There is a positive and significant effect of organizational commitment on job motivation with significant values $<0.05$. The higher the employee organizational commitment then also increase the employee motivation Sekretariat Daerah Kabupaten Dharmasraya..

3. There is a positive and significant impact on the performance of the work environment with significant values < 0.05. The better the work environment also increase the performance of the Staff Sekretariat Daerah Kabupaten Dharmasraya.

4. There is a positive and significant impact on the performance of the organization's commitment with significant values $<0.05$. The higher the employee organizational commitment then also increase the performance of the Staff Sekretariat Daerah Kabupaten Dharmasraya ..

5. There is a positive and significant effect of work motivation on employee performance with significant values < 0.05. Increasing motivation to work then also increase the performance of the Staff Sekretariat Daerah Kabupaten Dharmasraya. For that, it needs to increase motivation to work in order to increase the performance of employees.

6. There are no job motivation role in mediating the relationship between the work environment and employee performance to the value of the indirect influence that is smaller than its direct effect. Increasing motivation to work then do not play a role in improving the work environment influence on employee performance Sekretariat Daerah Kabupaten Dharmasraya.

7. There are no job motivation role in mediating the relationship between organizational commitment and performance of employees with no direct influence value smaller than its direct effect. Increasing motivation to work then do not play a role in increasing the influence of organizational commitment to employee performance Sekretariat Daerah Kabupaten Dharmasraya.

Furthermore, this research path structure can be described again as follows:

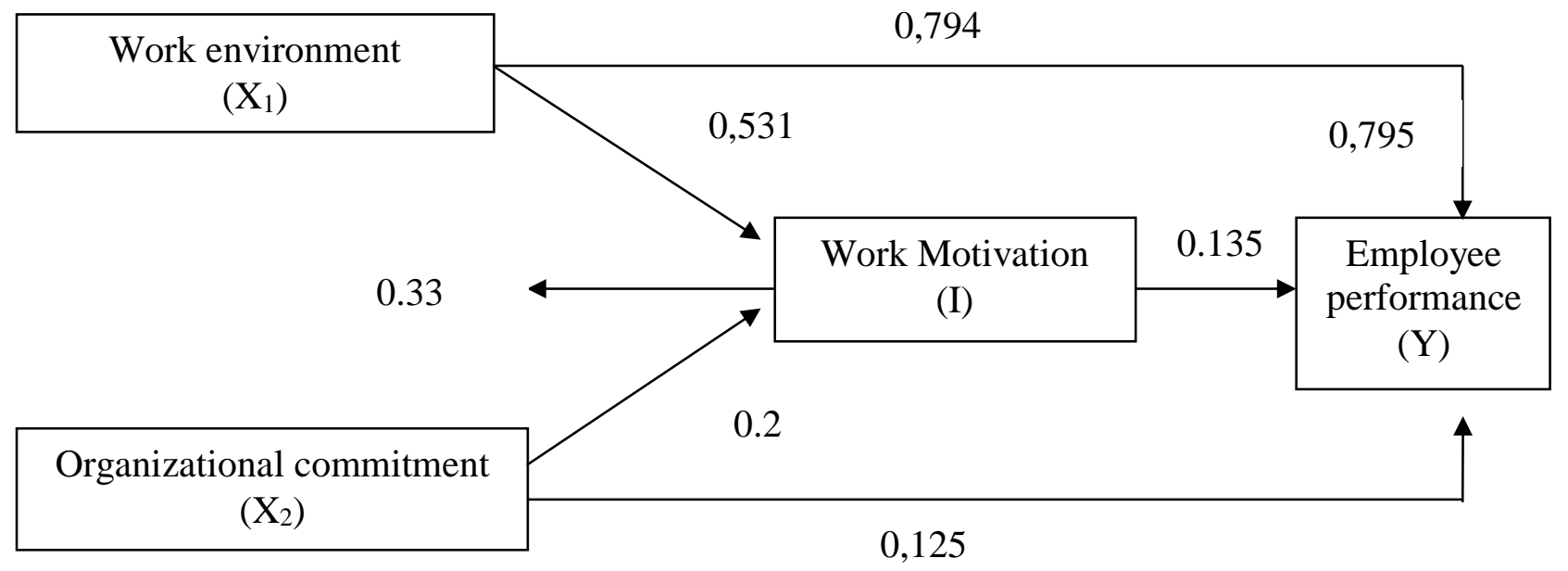

Figure 4

Path Analysis Model

\section{Limitations and Suggestions}

Researchers realized these results are still far from perfect and have weaknesses and limitations that may affect the outcome, for it kepaada future researchers is expected to be an improvement and development of deficiencies that researchers have encountered, such as:

a) The first study has a number of samples that are still relatively low at 77 employees Sekretariat Daerah Kabupaten Dharmasraya, The low number of samples resulting in low support or justification of these results, it is evident from the assessment found the interaction hypothesis does not look real or significant influence. To the researchers who will comeis expected to expand the number of population and sample, by setting research object more broadly by making objects organization that has employees more, or may take a few organizations that have any kind of surgery or the same service in the area or geography that are close together or region.

b) The use of questionnaires in data collection respondent has the disadvantage of differences in perception among respondents perceive and assess a variable. So the researchers in this case can not control the answers of the respondents, which ultimately can lead to low justiifikasi for the assessment of the validity of the data and the research hypothesis. Therefore, for researchers to comeexpected to use and look for other methods of data collection, 
Doli Putra Harahap et al, How Motivation Works to Promote the Relationship Between Work Environment and Organizational Commitment to the Performance of Dharmasraya District Secretariat

such as data retrieval jobs directly related to the object of respondents or using standardized assessment standards and is authorized by the competent officials.

c) These findings also indicate other factors can also affect the performance of employees. For the researchers, who will come to seek and findseveral suspected factors can affect the performance of employees, such as organizational culture, leadership style, job satisfaction, work discipline and competence.

\section{References}

Bernardin, H. J., \& Russel, J. E. . 1993. Human Resourses Management. New York: Mc Graw Hill Inc.

Daryanto, A. 2010. Merit system dalam manajemen pegawai negeri sipil. Kebijakan Dan Manajemen PNS.

Davis, Keith., J. W. N. 2001. Perilaku Dalam Organisasi (Terjemahan) Jilid I (Ed. 7). Jakarta: Erlangga.

Flippo, E. B. 2009. Humam Resource Management. Academy of Management Journal.

Ghozali, I. 2016. Aplikasi Analisis Multivariete Dengan Program IBM SPSS 23, Edisi 8. In Badan Penerbit Universitas Diponegoro.

Gibson, Ivancevich, D. 2010. Organisasi dan Manajemen : Perilaku, Struktur dan Proses. Organizational Behavior.

Handoko, H. 2010. Manajemen Personalia Sumber Daya Manusia, Edisi Kedua. BPFE UGM Persada.

Hasibuan. 2018. Manajemen Sumber Daya Manusia. Jakarta: Bumi Aksara.

Mangkunegara, A. A. A. P. 2013. Manajemen Sumber Daya Manusia Perusahaan. Remaja Rosdakarya.

Mangkunegara, A. A. A. P. 2016. Evaluasi Kerja. PT.Refika Aditama. https://doi.org/10.1038/cddis.2011.1

Mathis Robert, L., \& Jackson John, H. 2001. Manajemen Sumber Daya Manusia Buku 1. Edisi Pertama, Penerbit Salemba Empat, Jakarta.

Nitisemito, A. S. 2003. Manajemen Personalia. Jakarta: Graha Indonesia.

Pandji Anoraga. 2014. Psikologi Kerja. Jakarta: Rineka Cipta.

Rivai, V. 2005. Manajemen Sumber Daya Manusia Untuk Perusahaan : dari Teori ke Praktik. Edisi Pertama, Penerbit PT. Raja Grafindo Persada, Jakarta.

Robbins, S. P. 2001. Perilaku Organisasi : Konsep, Kontroversi dan Aplikasi. Prenhallindo.

Santoso, S. 2014. Statistik Multivariat Edisi Revisi. Jakarta: PT Elex Media Komputindo.

Sedarmayanti. 2009. Sumber Daya Manusia Dan Produktivitas Kerja.

Sedarmayanti. 2011. Reformasi Birokrasi dan Manajemen Pegawai Negeri Sipil. In Manajemen Sumber Daya Manusia.

Sedarmayanti. 2012. Good Governance: Kepemerintahan Yang Baik \& Good Corporate Governance: Tata Kelola Perusahaan Yang Baik. Bagian Ketiga, Edisi Revisi. Bandung: CV. Bandar Maju.

Sekaran, U. 2009. Metodologi Penelitian untuk Bisnis (Research Methods for Business). In 1.

Sopiah. 2008. Perilaku Organisasional. Yogyakarta: Andi Publisher.

Timpe. Dale. 2013. Seri Manajemen Sumber Daya Manusia Kinerja (Cetakan Ke). Jakarta: PT Elex Media Komputindo Kelompok Gramedia.

Winardi. 2004. Manajemen Perilaku Organisasi. Jakarta: Pustaka Binaman Pressindo. 